\title{
Upaya Meningkatkan Kemampuan Mengenal Lambang Bilangan melalui Bermain Puzzle Jam Anak Usia 4-5 tahun Di PAUD Generasi Bangsa Pekanbaru
}

\author{
Nurmiati Tanjung ${ }^{1)}$, Sean Marta Efastri ${ }^{2)}$ \\ ${ }^{1)}$ PAUD Generasi Bangsa \\ email: jummila500@gmail.com \\ ${ }^{2)}$ Universitas Lancang Kuning \\ email: seanmarta@unilak.ac.id
}

\begin{abstract}
Abstrak: Penelitian ini dilaksanakan karena masih rendahnya kemampuan mengenal lambang bilangan anak di PAUD Generasi Bangsa Pekanbaru. Untuk itu diperlukan suatu tindakan yang konkret agar dapat menemukan cara tepat berkenaan dengan kemampuan mengenal lambang bilangan anak, yaitu dengan bermain puzzle Jam. Penelitian ini bertujuan untuk mengetahui apakah kemampuan mengenal lambang bilangan dapat ditingkatkan melalui bermain puzzle Jam pada anak usia 4-5 tahun di PAUD Generasi Bangsa Pekanbaru. Jenis penelitian ini adalah penelitian tindakan kelas. Subjek dalam penelitian ini adalah anak lokal A yang berjumlah sebanyak 20 orang anak dengan rincian 11 anak laki-laki dan 9 anak perempuan. Dari hasil penelitian tindakan kelas dan pembahasan seperti telah diuraikan diperoleh kesimpulan terhadap hasil penelitian ini yaitu 1) Bermain puzzle Jam dapat meningkatkan kemampuan mengenal lambang bilangan anak usia 4-5 tahun di PAUD Generasi Bangsa Pekanbaru , 2) Kemampuan mengenal lambang bilangan anak usia 4-5 tahun di PAUD Generasi Bangsa Pekanbaru sebelum melalui bermain puzzle Jam berkriteria mulai berkembang (MB). Sesudah melalui bermain puzzle Jam pada siklus I dan II secara umum kemampuan mengenal lambang bilangan anak sudah berkembang sangat baik (BSB), 3) Dalam pengujian hipotesis dapat dilihat peningkatan yang diperoleh dari setiap siklusnya. Peningkatan kemampuan mengenal lambang bilangan yang diperoleh dari sebelum dilakukannya tindakan ke siklus I peningkatan sebesar $42,60 \%$. Sedangkan peningkatan kemampuan mengenal lambang bilangan dari siklus I ke siklus II sebesar 37,76\%, dan secara keseluruhan peningkatan kemampuan mengenal lambang bilangan dari data awal ke siklus II sebesar 96,45\%.
\end{abstract}

Kata Kunci : Bermain Puzzle Jam , Lambang Bilangan 


\title{
Efforts To Increase The Ability To Know The Symbol Clock Puzzle Numbers To Play Through Children 4-5 Years In The Generation Of Nations ECD Pekanbaru
}

\begin{abstract}
:
This research was carried out because of the low ability to recognize the symbol of child numbers in PAUD Generasi Bangsa Pekanbaru. For this reason, a concrete action is needed in order to find the right way regarding the ability to recognize the symbol of the child's number, namely by playing the Jam puzzle. This study aims to find out whether the ability to recognize the number symbol can be improved through playing puzzle hours for children aged 4-5 years in the Generation Generation Pekanbaru. This type of research is classroom action research. Subjects in this study were local children A, amounting to 20 children with details of 11 boys and 9 girls. From the results of action research and discussion as described conclusion to this research are: 1) Play puzzle clock can improve the ability to know the epitome number of children aged 4-5 years in early childhood Pekanbaru Generation Nation, 2) The ability to know the symbol number of children aged 4- 5 years in the Generasi Bangsa Pekanbaru PAUD before going through the criteria clock playing puzzle began to develop (MB). After going through the clock puzzle in cycle I and II in general, the ability to recognize the symbol of child numbers has developed very well (BSB), 3) In testing the hypothesis can be seen the increase obtained from each cycle. Increased ability to recognize the number symbol obtained from before the action to cycle I increased by $42.60 \%$. While the increase in the ability to recognize the symbol number from cycle I to cycle II is $37.76 \%$, and overall the increase in the ability to recognize the number symbol from the initial data to the second cycle is $96.45 \%$.
\end{abstract}

Keywords: Playing Clock Puzzle, Number Symbol

\section{PENDAHULUAN}

Pendidikan pada anak usia dini, dalam hal ini anak usia Taman Kanak-Kanak pada dasarnya meliputi seluruh upaya dan tindakan yang dilakukan oleh pendidik/guru dan orang tua dalam proses perawatan, pengasuhan dan pendidikan pada anak dengan menciptakan lingkungan dimana anak dapat mengeksplorasi pengalaman yang dapat memberikan

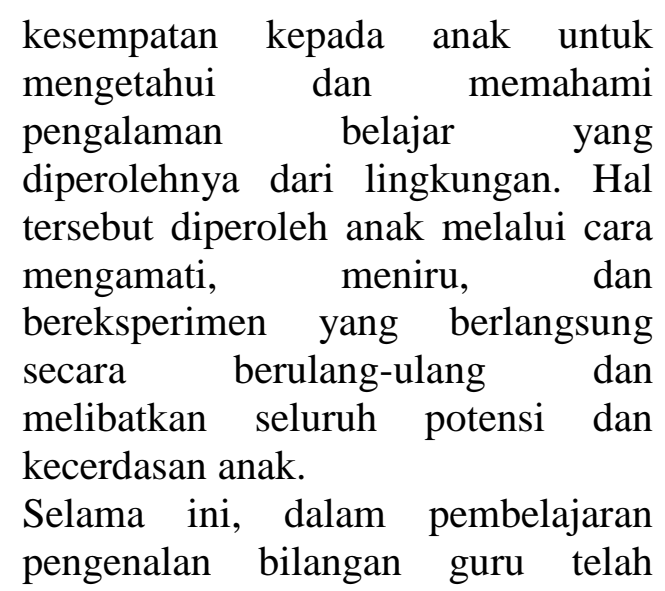


menerapkan dengan beberapa metode pembelajaran seperti latihan, ceramah ataupun tanya jawab yang ternyata kurang memberikan hasil yang optimal. Meskipun guru telah menjelaskan secara berulang-ulang, namun hasil belajar siswa khususnya pada materi mengenal bilangan belum memuaskan. Untuk itu diperlukan pembelajaran yang dapat meningkatkan kemampuan anak. Salah satu pembelajaran yang dapat diterapkan adalah pembelajaran puzzle jam. Diana (2010:49) mengemukakan permainan sebagai suatu media yang dapat meningkatkan perkembangan mengenal lambang bilangan anak, permainan memungkinkan anak mempraktekan potensi. Keterampilan-keterampilan yang diperlukan dengan santai dan menyenangkan bagi anak, misalnya anak belajar mengenal angka dari puzzle jam.

Permainan puzzle jam yang sangat disukai anak-anak dari usia 4-5 tahun hingga usia dewasa, permainan puzzle jam adalah suatu permainan dengan menggunakan media triplek ukuran 30x20 cm yang diberi gambar sebuah jam lengkap dengan jarum penunjuk. Potongan yang diberi angka dapat dilepas pasang, kemudia anak diminta untuk menyusun kembali angka-angka sesuai dengan arah jarum jam. Diharapkan dengan permainan ini, anak dapat lebih mudah mengenal lambang bilangan. Kita selalu mengenal istilah bilangan simbol atau lambang yang digunakan untuk mewakili suatu bilangan yang disebut angka. Mengenal bilangan pada anak sudah dapat dimulai melalui melihatkan pada anak urutan bilangan dengan benda-benda yang sudah sering dilihat oleh anak Sehingga anak diharapkan dapat mengenal waktu dan mengenal lambang bilangan serta dapat membedakan antara banyak dan sedikit.

Berdasarkan fenomena di kelas A PAUD Generasi Bangsa Pekanbaru, peneliti melihat rata-rata kemampuan anak dalam mengenal konsep bilangan masih sedikit atau tergolong rendah, hal ini dapat dilihat dari : 1) Dari 20 anak didik secara umum hanya 5 orang atau $25 \%$ yang dapat anak dapat membilang/ menyebutkan konsep bilangan dengan benda satu hingga sepuluh, 2) Dalam hal mencocokkan bilangan dengan lambang bilangan, terdapat hanya sedikit yang bisa melakukannya yaitu hanya 3 anak atau $15 \%$ saja, 3) Hanya sebahagian kecil anak yaitu 4 orang atau $20 \%$ anak yang bisa mengenal konsep bilangan.

Diharapkan dengan Bermain Puzzle jam tersebut, anak dapat mengenal, menyebutkan, menyusun, dan measangkan urutan anka dan benda dari 1 sampai angka tertentu. Hal ini disebabkan karena permainan ini cukup menarik dengan tampilan media puzzle jam yang bagus dengan angka yang beraneka warna, sehingga anak akan semakin senang untuk mencobanya. Berdasarkan latar belakang masalah yang telah diuraikan maka telah dilakukan penelitian dengan judul "Upaya Meningkatkanan Kemampuan Mengenal Lambang Bilangan Melalui Bermain Puzzle jam Anak Usia 4-5 Tahun Di PAUD Generasi Bangsa Pekanbaru". 


\section{KAJIAN TEORI}

Kemampuan

mengenal

lambang bilangan merupakan suatu kemampuan yang dimiliki anak dalam mengetahui lambang bilangan dan dapat membedakan lambang bilangan yang satu dengan lambang bilangan yang lainnya. Anak dapat menggunakan dan mengolah lambang bilangan dalam kehidupan sehari-hari.

Sudrajat, (2003:50) Bilangan adalah suatu konsep matematika yang digunakan untuk pencacahan dan pengukuran. Simbol ataupun lambang yang digunakan untuk mewakili suatu bilangan disebut sebagai angka atau lambang bilangan. Dalam matematika, konsep bilangan selama bertahun-tahun lamanya telah diperluas untuk meliputi bilangan nol, bilangan negatif, bilangan rasional, bilangan irasional, dan bilangan kompleks. Prosedur-prosedur tertentu yang mengambil bilangan sebagai masukan dan menghasil bilangan lainnya sebagai keluaran, disebut sebagai operasi numeris. Operasi uner mengambil satu masukan bilangan dan menghasilkan satu keluaran bilangan. Operasi yang lebih umumnya ditemukan adalah operasi biner, yang mengambil dua bilangan sebagai masukan dan menghasilkan satu bilangan sebagai keluaran. Contoh operasi biner adalah penjumlahan, pengurangan, perkalian, pembagian, dan perpangkatan. Bidang matematika yang mengkaji operasi numeris disebut sebagai aritmetika.

Yuliani

mengemukakan bahwa memahami adalah kemampuan untuk mengingat dan menggunakan informasi serta menerjemahkan, memperhitungkan atau meramalkan kemungkinan. Kemampuan anak dalam mengenal bilangan tidak sama, hal ini dapat dilatar belakangi oleh faktor internal dan faktor eksternal misalnya lingkungan yang terdidik, ekonomi dan kesehatan. Di dalam kehidupan sehari-hari selalu dikenal istilah bilangan simbol atau lambang yang digunakan untuk mewakili suatu bilangan disebut angka. Bilangan merupakan bagian dari matematika, sedangkan matematika merupakan bagian dari perkembangan kemampuan kognitif. Mengenal bilangan pada anak sudah dapat dimulai melalui melihatkan pada anak urutan bilangan dengan bendabenda yang sudah sering dilihat oleh anak.

Bronson (Rita, 2009:118) mengemukakan bahwa anak mempelajari konsep matematika melalui kegiatan menghitung benda kongkrit, menghubungkan jumlah dengan konsep angka, dan mengembangkan konsep menambah serta mengurang setelah itu. Dalam Kamus Besar Bahasa Indonesia (2009:150) bilangan diartikan sebagai satuan dalam sistem matematis yang abstrak dan dapat diunitkan, ditambah atau dikalikan.

$$
\text { Sudaryanti }
$$

(2006:1)

mengemukakan bahwa untuk menyatakan suatu bilangan dinotasikan dengan lambang bilangan yang disebut angka. Bilangan dengan angka menyatakan dua konsep yang berbeda, bilangan berkenaan dengan nilai sedangkan angka bukan nilai. Angka hanya merupakan suatu notasi tertulis dari sebuah bilangan. perlu adanya pembeda antara tanda bilangan dengan operasi pada 
bilangan, karena tanda bilangan menyangkut nilai bilangan itu. Untuk menyatakan bilangan suatu lambang atau simbol yang disebut dengan angka. pengertiannya, antara bilangan dengan lambang bilangan sangat berbeda. Bilangan menyatakan suatu kuantitas, sedangkan angka adalah notasi dari bilangan tersebut.

Sebelum dipaparkan lebih jauh mengenai kartu bergambar, peneliti akan menjelaskan pengertian media, karena puzzle jam merupakan salah satu bentuk media yang digunakan dalam pembelajaran. Sadiman (2008:6) menyatakan bahwa media berasal dari bahasa latin dan merupakan bentuk jamak dari medium yang secara harafiah berarti perantara atau pengantar. Media dalah perantara atau pengantar pesan dari pengirim ke penerima pesan. Hamdani (2011:72) mengemukakan bahwa media apabila dipahami secara garis besar adalah manusia, materi, atau kejadian yang membangun kondisi yang membuat siswa mampu memperoleh pengetahuan, keterampilan, atau sikap. Selain membangkitkan motivasi dan minat siswa, media pembelajaran juga dapat membantu siswa meningkatkan pemahaman, menyajikan data dengan menarik dan terpercaya, memudahkan penafsiran data dan memadatkan infomasi.

Mengenai pengertian media hampir semua ahli sependapat dalam merumuskannya. Menurut Jusni, (2006:6) mengemukakan bahwa media pengajaran adalah alih ujud dari pada bahan ajar atau target hasil dan proses belajar yang dapat digunakan untuk menyalurkan pesan (message), merangsang pikiran, perasaan, perhatian, dan kemauan anak sehingga dapat mendorong proses belajar. Lebih lanjut Jusni (2006:6) mengemukakan media adalah segala bentuk alat perantara yang digunakan orang untuk menyampaikan sesuatu (informasi, gagasan, dan sebagainya kepada orang lain). Dengan demikian media pendidikan adalah media yang penggunaannya diintegrasikan dengan tujuan dan isi pelajaran, serta maksud untuk lebih meningkatkan mutu mengajar dan belajar.

$$
\text { Sudjana }
$$

mengemukakan bahwa penggunaan media tidak dilihat atau dinilai dari segi kecanggihan medianya, tetapi yang lebih penting adalah fungsi dan peranannya dalam membantu mempertinggi proses pengajaran. Oleh sebab itu, penggunaan media pengajaran sangat tergantung kepada tujuan pengajaran, bahan pengajaran, kemudahan memperoleh media yang diperlukan serta kemampuan guru dalam menggunakanya dalam proses pengajaran.

Arsyad

(2010:6), mendeskripsikan manfaat media pembelajaran dalam proses belajar siswa yaitu:

a. Pembelajaran akan lebih menarik perhatian siswa sehingga dapat menumbuhkan motivasi belajar.

b. Bahan pembelajaran akan lebih jelas maknanya sehingga dapat lebih dipahami oleh sisa dan memungkinkannya menguasai dan mencapai tujuan pembelajaran.

c. Metode belajar akan lebih bervariasi, tidak semata-mata komunikasi verbal melalui penuturan kata-kata oleh guru, sehingga siswa tidak bosan dan guru tidak kehabisan 
tenaga, apalagi jika guru mengajar setiap jam pelajaran.

d. Siswa lebih banyak melakukan kegiatan belajar sebab tidak hanya mendengarkan uraian guru, tetapi juga kativitas lain seperti mengamati, melakukan, memerankan, dan lain-lain.

Dari beberapa penjelasan di atas dapat disimpulkan bahwa media pembelajaran adalah segala sesuatu yang dapat digunakan untuk menyalurkan pesan dari pengirim ke penerima sehingga dapat merangsang pikiran, perasaan, minat serta perhatian anak sedemikian rupa sehingga proses belajar menjadi lebih hidup. Media pengajaran dapat menstimulasi belajar siswa atau membantu siswa terutama untuk mengkongkretkan berbagai konsepnya yang sifatnya abstrak. Melalui media siswa lebih terminat untuk belajar, karena siswa berusaha memahami suatu materi pelajaran secara lebih nyata.

$$
\text { Eliyawati }
$$

mengemukakan bahwa Alat

Permainan Edukatif (APE) adalah semua alat yang digunakan anak untuk memenuhi kebutuhan naluri bermainnya. Berbeda dengan alat permainan umumnya, alat permainan edukatif banyak ditemukan di lembaga-lembaga penyelenggara program pendidikan anak usia dini (kelompok bermain maupun Taman kanak-kanak). Secara spesifik berkaitan dengan alat permainan anak usia dini, maka pengertian APE untuk anak usia dini adalah alat permainan yang dirancang untuk tujuan meningkatkan aspek-aspek perkembangan anak usia dini.

Wahyuni media visual dua dimensi yang mempunyai kemampuan untuk menyampaikan informasi secara visual tentang segala sesuatu sebagai pindahan dari wujud yang sebenarnya. Ismail, A. (2006:218) puzzle adalah permainan yang menyusun suatu gambar atau benda yang telah dipecah dalam beberapa bagian. Permainan puzzle melibatkan koordinasi mata dan tangan. Namun secara khusus puzzle biasanya terbentuk dari sebuah gambar yang terpotong-potong bagian tertentu. Puzzle dapat terbuat dari plastik, spon, kertas, ataupun kayu tebal. Bahan puzzle yang paling baik bagi kegiatan belajar mengajar adalah dari kayu. Guru dapat menggunakan puzzle ini untuk mengarahkan anak pada pelajaran yang akan diajarkan pada saat itu.

$$
\text { Puzzle jam adalah suatu }
$$

permainan dengan menggunakan media triplek ukuran $30 \times 20 \mathrm{~cm}$ yang diberi gambar sebuah jam lengkap dengan jarum penunjuk. Potongan yang diberi angka dapat dilepas pasang, kemudia anak diminta untuk menyusun kembali angka-angka sesuai dengan arah jarum jam. Cara kerjanya adalah dengan cara mengambil keping-keping kemudian anak diminta untuk menyusun kembali angka-angka sesuai arah jarum jam. Dari penjelasan tersebut diatas maka dapat disimpulkan bahwa puzzle adalah permainan tekateki menyatukan kembali beberapa bagian objek yang acak pada tempatnya yang sesuai. 


\section{METODOLOGI PENELITIAN}

Metode yang digunakan dalam penelitin ini yakni berjenis penelitian tindakan kelas (PTK). Menurut Rochiati (2012:78) penelitian tindakan kelas (PTK) adalah upaya perbaikan pelaksanaan praktek pendidikan oleh sekelompok guru dengan melakukan tindakan-tindakan dalam pembelajaran. Tindakan kelas yang peneliti lakukan pada penelitian adalah upaya meningkatkan kemampuan mengenal lambang bilangan melalui bermain puzzle jam pada anak usia 4-5 tahun di Paud Generasi Bangsa Pekanbaru. Penelitian ini dilakukan dalam 2 siklus setiap siklus dilakukam 3 kali pertemuan untuk melihat peningkatan kemampuan mengenal mengenal lambang bilangan anak melalui penggunaan media bermain puzzle jam.

Ada beberapa ahli yang mengungkapkan model penelitian tindakan kelas dengan bagan yang berbeda, namun secara garis besar terdapat empat tahapan lazim yang dilalui, yaitu : 1) Perencanaan, 2) Pelaksanaan, 3) Pengamatan atau observasi, 4) refleksi.

Subjek penelitian merupakan suatu hal yang menjadi inti dari penelitian yang nantinya digunakan untuk memperoleh data penelitian, adapun subjek dalam penelitian ini adalah:

\section{Teknik Pengumpulan Data}

Untuk mendapatkan data yang konkrit dan benar-benar mendukung hasil penelitian, maka penulis mengambil dan mengumpulkan data dari observasi adalah dengan melakukan pengamatan langsung ke lokasi penelitian untuk mengetahui keadaan yang terlihat pada objek penelitian. Untuk mendapatkan data yang konkrit dan benar-benar mendukung hasil penelitian, maka penulis mengambil dan mengumpulkan dua dari observasi dan dokumentasi.

\section{Teknik Analisa Data}

Data yang diperoleh pada penelitian ini adalah data tentang mengenal lambang bilangan, dianalisis dengan teknik analisis deskriptif. Analisis data yang dilakukan secara deskriptif bertujuan untuk menggambarkan data tentang aktivitas guru dan anak selama proses pembelajaran, dan data ketercapaian mengenal lambang bilangan anak usia 4-5 tahun. Untuk menentukan peningkatan mengenal lambang bilangan anak diolah dengan menggunakan rumus persentase, yaitu sebagai berikut :

$\mathrm{P}=\underline{\text { Posrate }- \text { Baserate }} \times 100 \%$ Baserate

Keterangan:

$\mathrm{P} \quad=$ Persentase peningkatan

Posrate $=$ Nilai sesudah tindakan

Baserate $=$ Nilai sebelum tindakan

$100 \%$ = Bilangan Tetap

Untuk mendeskripsikan data kemampuan keberhasilan aktivitas guru dan aktivitas anak selama proses pembelajaran diolah dengan menggunakan rumus persentase, yaitu sebagai berikut :

$$
p=\frac{\mathrm{F}}{\mathrm{N}} \times 100 \%
$$

Keterangan:

$$
\begin{array}{ll}
\mathrm{f} \quad \text { Frekuensi yang sedang } \\
\\
\begin{array}{l}
\text { dicari } \\
\text { persentasenya }
\end{array} \\
\mathrm{N} \quad \text { Number of Cases (jumlah }
\end{array}
$$


individu)

frekuensi/banyaknya

$\mathrm{P} \quad=$ Angka persentase

$100 \%$ = Bilangan Tetap

\section{HASIL DAN PEMBAHASAN} Hasil Penelitian

Tabel 1. Rekapitulasi Kemampuan Mengenal lambang bilangan Anak Pada Siklus I

\begin{tabular}{|c|c|c|c|c|c|}
\hline NO & INDIKATOR & $\begin{array}{l}\text { Siklus I } \\
\text { Pert } 1 \\
\%\end{array}$ & $\begin{array}{l}\text { SiklusI } \\
\text { Pert2 } \\
\%\end{array}$ & $\begin{array}{c}\text { Siklus } 1 \\
\text { Pert3 } \\
\%\end{array}$ & $\begin{array}{l}\text { Rata-Rata } \\
\%\end{array}$ \\
\hline 1 & $\begin{array}{l}\text { Anak dapat membilang bannyak } \\
\text { benda satu sampai sepuluh }\end{array}$ & 50.00 & 60.00 & 73.75 & 61.25 \\
\hline 2 & $\begin{array}{l}\text { Anak dapat Mencocokkan bilangan } \\
\text { dengan lambang bilangan }\end{array}$ & 48.75 & 63.75 & 72.50 & 61.67 \\
\hline 3 & $\begin{array}{l}\text { Anak dapat mengatur angka-angka } \\
\text { membentuk deretan yang sesuai } \\
\text { dengan arah jarum jam }\end{array}$ & 50.00 & 61.25 & 68.75 & 60.00 \\
\hline 4 & $\begin{array}{l}\text { Anak dapat mengenal konsep } \\
\text { bilangan }\end{array}$ & 48.75 & 58.75 & 67.50 & 58.33 \\
\hline 5 & $\begin{array}{l}\text { Anak mengetahui konsep banyak } \\
\text { dan sedikit }\end{array}$ & 50.00 & 61.25 & 68.75 & 60.00 \\
\hline & Jumlah & 248 & 305 & 351 & 301.25 \\
\hline & Rata-rata & 49.50 & 61.00 & 70.25 & 60.25 \\
\hline & Kriteria & $M B$ & BSH & BSH & BSH \\
\hline
\end{tabular}

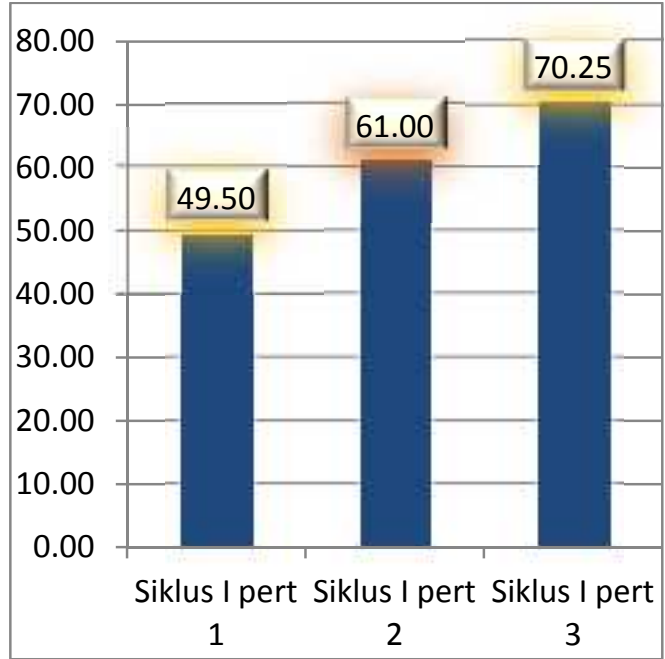

Grafik Mengenal lambang bilangan Anak Pada siklus I pertemuan 1, pertemuan 2 , pertemuan 3

Kemampuan mengenal lambang bilangan pada anak usia 4-5 tahun di PAUD Generasi Bangsa Pekanbaru dapat dijelaskan bah pada siklus I pertemuan pertama diperoleh nilai rata-rata 49,50. Pada siklus I pertemuan kedua diperoleh nilai rata-rata 61,00 dan siklus I pertemuan ketiga diperoleh nilai ratarata 70,25 .

Tabel 2. Rekapitulasi Kemampuan Mengenal Lambang Bilangan Siklus II 


\begin{tabular}{|c|c|c|c|c|c|}
\hline \multirow[t]{2}{*}{ No } & \multirow[t]{2}{*}{ Indikator } & $\begin{array}{l}\text { Siklus II } \\
\text { Pert I }\end{array}$ & $\begin{array}{l}\text { Siklus II } \\
\text { Pert } 2\end{array}$ & $\begin{array}{l}\text { Siklus II } \\
\text { Pert } 3\end{array}$ & Rata-Rata \\
\hline & & $\%$ & $\%$ & $\%$ & $\%$ \\
\hline 1 & $\begin{array}{l}\text { Anak dapat membilang banyak } \\
\text { benda satu sampal sepuluh }\end{array}$ & 75.00 & 85.00 & 91.25 & 83.75 \\
\hline 2 & $\begin{array}{l}\text { Anak dapat Mencocokkan bilangan } \\
\text { dengan lambang bilangan }\end{array}$ & 76.25 & 87.50 & 88.75 & 84.17 \\
\hline & $\begin{array}{l}\text { Anak dapat mengatur angka-angka } \\
\text { membentuk deretan yang sesuai } \\
\text { dengan arah jarum jam }\end{array}$ & 75.00 & 83.75 & 87.50 & 82.08 \\
\hline & $\begin{array}{l}\text { Anak dapat mengenal konsep } \\
\text { bilangan }\end{array}$ & 72.50 & 85.00 & 91.25 & 82.92 \\
\hline 5 & $\begin{array}{l}\text { Anak mengetahui konsep banyak } \\
\text { dan sedikit }\end{array}$ & 75.00 & 83.75 & 87.50 & 82.08 \\
\hline & Jumlah & 374 & 425 & 446 & 415.00 \\
\hline & Ratar-rata & 74.75 & 85.00 & 89.25 & 83.00 \\
\hline & Kriteria & BSH & BSB & BSB & BSB \\
\hline
\end{tabular}

\begin{tabular}{|c|c|c|c|c|}
\hline NO & NDIKATOR & $\begin{array}{c}\text { PRA } \\
\text { SIKLUS }\end{array}$ & SIKLUSI & SIKLUSII \\
\hline & $\begin{array}{l}\text { Anak dapat membilang banyak benda satu } \\
\text { sampai sepuluh }\end{array}$ & 43.75 & 61.25 & 8375 \\
\hline 2 & $\begin{array}{l}\text { Anak dapat Mencocockkan bilangan dengan } \\
\text { lambang bilangan }\end{array}$ & 43.75 & 61.67 & 84.17 \\
\hline 3 & Anak dapat mengagatur angkka-ngoka membentuk & 42.50 & 60.00 & 82.08 \\
\hline 4 & Anak dapat mengenal konsep bilangan & 40.00 & 58.33 & 82,92 \\
\hline 5 & Anak mengetahui konsep banyak dan sedikit & 41.25 & 60.00 & 82.08 \\
\hline & Jumlah & 211.25 & 301.25 & 415.00 \\
\hline & Rata-rata & 42.25 & 60.25 & 83.00 \\
\hline & Kriteria & MB & BSH & BSB \\
\hline
\end{tabular}

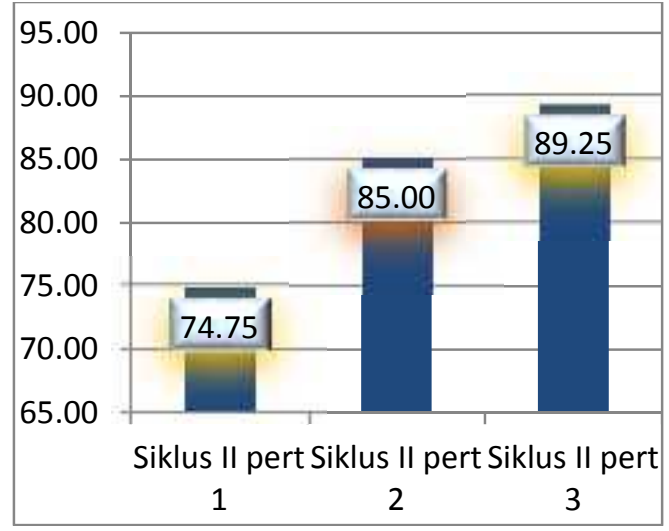

Grafik Mengenal lambang bilangan Anak Pada siklus II pertemuan 1, pertemuan 2 , pertemuan 3

kemampuan mengenal lambang bilangan anak pada siklus II sebesar 83\% dengan kriteria berkembang baik, seperti yang terlihat pada tabel berikut ini.

Tabel 3. Rekapitulasi Kemampuan Mengenal lambang bilangan Anak Pada Siklus I Dan Siklus II ratakan kemampuan mengenal lambang bilangan mengalami peningkatan dari data awal ke siklus I dan ke siklus II. Pada data awal diperoleh persentase 42,25\%, Pada siklus I diperoleh persentase $60,25 \%$, sedangkan pada siklus II diperoleh persentase sebesar $83,00 \%$.

Agar lebih jelas hasil kemampuan mengenal lambang bilangan anak melalui bermain puzzle jam mengalami peningkatan mulai dari data awal, Siklus I dan Siklus II, dapat dilihat pada grafik berikut: 


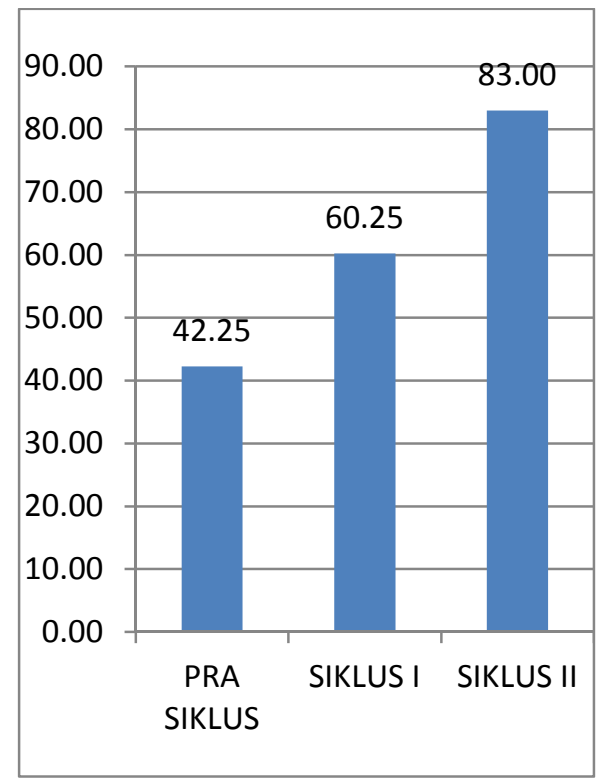

1. Dari

hasil

observasi

perkembangan aspek yang diamati pada pra siklus terdapat nilai rata-rata 42,25 dan pada siklus I terdapat nilai rata-rata 60,25. Setelah dianalisis terjadi peningkatan sebesar $42,60 \%$ dari pra siklus ke siklus I. Untuk mengetahui persentase dari data awal ke siklus I sebagai berikut:

$$
\begin{aligned}
& P=\frac{60,25-42,2}{42,25} \\
& =\frac{18}{42,25} \times 100 \% \\
& =0,43 \times 100 \% \\
& =42,60 \%
\end{aligned}
$$

\section{Dari hasil observasi} perkembangan aspek yang diamati pada siklus 1 terdapat nilai rata-rata 60,25 dan pada siklus II terdapat nilai rata-rata 83,00. Setelah dianalisis terjadi peningkatan sebesar $37,76 \%$ dari siklus I ke siklus II. Untuk mengetahui persentase dari siklus pertama ke siklus kedua sebagai berikut:

$$
\begin{aligned}
& P=\frac{83,00-60,25}{60,25} \times 100 \% \\
& =\frac{22,75 \times 100 \%}{60,25} \\
& =0,38 \times 100 \% \\
& =37,76 \%
\end{aligned}
$$

3. Dari hasil observasi perkembangan aspek yang diamati pada pra siklus terdapat nilai rata-rata 42,25 dan pada siklus II terdapat nilai rata-rata 83,00 Setelah dianalisis terjadi peningkatan sebesar $96,45 \%$ dari data awal ke siklus II. Untuk mengetahui persentase dari data awal ke siklus kedua sebagai berikut:

$$
\begin{aligned}
& 42,25 \\
= & \frac{40,75}{42,25} \times 100 \% \\
= & 0,97 \times 100 \% \\
= & 96,45 \%
\end{aligned}
$$$$
\mathrm{P}=\underline{83,00-42,25} \times 100 \%
$$

Dengan adanya peningkatan persentase pada setiap pertemuan, maka hal ini menunjukkan bahwa melalui bermain puzzle jam dapat meningkatkan kemampuan mengenal lambang bilangan pada anak uisa 4-5 tahun di PAUD Generasi Bangsa Pekanbaru.

\section{KESIMPULAN}

Dari hasil penelitian tindakan kelas dan pembahasan seperti telah diuraikan diperoleh kesimpulan terhadap hasil penelitian ini yaitu:

1. Bermain puzzle jam dapat meningkatkan kemampuan mengenal lambang bilangan anak usia 4-5 
tahun di PAUD Generasi Bangsa Pekanbaru.

2. Kemampuan mengenal lambang bilangan anak usia 4-5 tahun di PAUD Generasi Bangsa Pekanbaru sebelum melalui bermain puzzle jam berkriteria mulai berkembang (MB). Sesudah melalui bermain puzzle jam pada siklus I dan II secara umum kemampuan mengenal lambang bilangan anak sudah berkembang sangat baik (BSB).

3. Dalam pengujian hipotesis dapat dilihat peningkatan yang diperoleh dari setiap siklusnya. Dimana peningkatan kemampuan mengenal lambang bilangan yang diperoleh dari sebelum dilakukannya tindakan ke siklus I peningkatan sebesar $42,60 \%$. Sedangkan peningkatan kemampuan mengenal lambang bilangan dari siklus I ke siklus II sebesar 37,76\%, dan secara keseluruhan peningkatan kemampuan mengenal lambang bilangan dari data awal ke siklus II sebesar 96,45\%.

Berdasarkan simpulan di atas maka peneliti menyampaikan rekomendasi sebagai berikut:

1. Akademisi

a. Bagi Guru

Guru agar dapat mengembangkan kegiatan belajar mengajar yang lebih kreatif memotivasi anak dapat meningkatkan kemampuan mengenal lambang bilangan. Metode pembelajaran harus menarik perhatian anak seperti pada penelitian melalui bermain puzzle jam.

b. Bagi sekolah

Sekolah bisa melakukan supervisi terhadap guru untuk bisa memberi pembekalan bagi guru dalam menciptakan dan menemukan serta memiliki media melalui bermain puzzle jam yang tersedia di alam yang tepat guna dan menyenangkan.

2. peneliti

a. Bagi Peneliti

Untuk peneliti diharapkan lebih mampu menguasai dan berinovasi segala bentuk kegiatan yang dilakukan dalam upaya meningkatkan kemampuan mengenal lambing bilangan pada anak.

b. Bagi Peneliti Selanjutnya

Untuk peneliti berikutnya diharapkan untuk meneliti lebih dalam mengenai peningkatan kemampuan mengenal lambang bilangan anak dengan media bermain yang lainnya.

\section{DAFTAR PUSTAKA}

[1] Aqib 2007. Penelitian Tindakan Kelas. Bandung. CV Yrama Widya

[2] Azhar. 2006. Media Pembelajaran. Jakarta : Rajawali Perss

[3] Dhieni. 2006. Metode Pengembangan Bahasa. Jakarta : Universitas Terbuka.

[4] Diana. 2010. Psikologi Bermain Anak Usia Dini. Jakarta : Fajar Interpratama

[5] Diah. 2014. Puzzle sebagai media pembelajaran untuk meningkatkan motivasi belajar siswa TK Budi Rahayu Yogyakarta. Jurnal Penelitian

[6] Depdikbud, 2002. Kamus Besar Bahasa Indonesia Jakarta: Balai Pustaka

[7] Eliyawati. 2005. Pemilihan dan Pengembangan Sumber Belajar Untuk Anak Usia Dini. Jakarta : Depdiknas. 
[8] Hamdani. 2011. Strategi Belajar Mengajar. Bandung : Pustaka Setia

[9] Yuliani. 2005. Metode Pengembangan Kognitif. Jakarta : Universitas Terbuka. 